\title{
From sacred cow to cash cow: The shifting political ecologies of protected areas in Russia
}

\author{
Müller, Martin
}

\begin{abstract}
How have political and economic processes in Russia impacted protected areas? When first conceived in 1916, protected areas in Russia were considered as sancta of nature. In post-Soviet times, however, the fortunes of protected areas have undergone swift change: from a period of liberalisation and a conservation bonanza in the 1990s to increasing exploitation in the 2000s and commodification in the 2010s. Against the historical background of the Soviet period, this contribution traces reserves' trajectory from sacred cows to cash cows. It concludes that the neoliberal impetus of introducing market principles into conservation is in danger of going off course in Russia: instead of making the market work for conservation, it makes conservation work for the market.
\end{abstract}

Posted at the Zurich Open Repository and Archive, University of Zurich ZORA URL: https://doi.org/10.5167/uzh-100273

Journal Article

Published Version

Originally published at:

Müller, Martin (2014). From sacred cow to cash cow: The shifting political ecologies of protected areas in Russia. Zeitschrift für Wirtschaftsgeographie, 58(2-3):127-143. 


\title{
From sacred cow to cash cow: The shifting political ecologies of protected areas in Russia
}

\begin{abstract}
How have political and economic processes in Russia impacted protected areas? When first conceived in 1916, protected areas in Russia were considered as sancta of nature. In post-Soviet times, however, the fortunes of protected areas have undergone swift change: from a period of liberalisation and a conservation bonanza in the 1990 s to increasing exploitation in the 2000s and commodification in the 2010s. Against the historical background of the Soviet period, this contribution traces reserves' trajectory from sacred cows to cash cows. It concludes that the neoliberal impetus of introducing market principles into conservation is in danger of going off course in Russia: instead of making the market work for conservation, it makes conservation work for the market.
\end{abstract}

Keywords: protected areas, conservation, political ecology, neoliberalism, commodification, Russia

\section{Introduction}

If there is a current trend in nature conservation, it is that of neoliberal conservation. The spread of market principles - the hallmark of neoliberalism - has begun to encompass what was once considered one of the last sanctuaries: nature and its protection. Conservation economics has become a reputable discipline whose expertise is much sought-after (MAYER/JOB 2014). A recent memorandum of German scientists - economists and ecologists alike - declares that "nature is a capital that is worth protecting. Its wealth is, however, difficult to maintain against the power of a globalised market. There is a greater chance of success if the market itself is used as an instrument in protecting nature" (HAMPICKE/ WäTZOLD 2009). Rather than work against the juggernaut of the market, let us work with it, this memorandum suggests. In other words, protecting nature might be more successful if it rests on a sound economic rationale.

Approaches to linking conservation with market principles and attaching a value to it have mushroomed in the recent past (cf. ARSEL/BÜSCHER 2012; BECKEN/JOB 2014). Under the banner of 'use it or lose it', payments for ecosystem services, biodiversity derivatives and species banking have joined initiatives to create markets for endangered species. Controversial recent proposals have included a suggestion to save the whales through introducing hunting quotas and then selling them to the highest bidder - whether conservationist or whale hunter (COSTELLO et al. 2012). The TEEB initiative, short for The Economics of Ecosystems and Biodiversity, is an international attempt to establish a standard basis for natural capital accounting and thus capture and quantify the value of nature and its conservation. Other studies have sought to measure the economic impact of protected areas (e. g. MAYER 2014; MAYER et al. 2010).

The argument in favour of applying market principles to conservation is patent: Internalising externalities guarantees a monetary valuation of the benefits of protecting nature and an accounting of the costs of inflicting damage on it. For protected areas, a study found that annual investments of 45 bn US\$ would yield annual benefits in the range of 4400 bn US\$ to 5200 bn US \$ - a "strikingly good bargain" (BALMFORD et al. 2002, 952). Showing that protected areas are bargains and not drags on economic development is also important when it comes to locals' attitudes towards them. That protected areas make good economic sense could help convince the frequent sceptics to turn out in greater support of them (STOLL-KLEEMANN/ Jов 2008). Critics point out, however, that the protection of nature should be justified on the basis of ethical rather than economic considerations. For what happens if a species or habitat turn out to be of less value than the proposed human use? 
Questions of the economic valuation and benefit of protected areas have a dual relevance for Russia. For one thing, Russia has one of the largest networks of protected areas worldwide. About two million square kilometres - five times the size of Germany - fall under some form of territorial protection. This is equivalent to about $12 \%$ of the Russian terrestrial area. About onefifth of this area is under strict protection (IUCN categories Ia/b and II) (cf. Tab. 2). Russian protected areas, however, have struggled to attract viable financing and be recognised as more than mere obstacles to economic development. For another, recent policies have elevated the exploitation of the economic potential of reserves, often through tourism. While earlier protected areas were regarded as conserving nature for its own sake, administrations have more and more come under pressure to demonstrate the economic viability of their operations (MÜLLER et al. 2011). In a twist of the neoliberal conservation logic, reserves have moved from being sacred cows to becoming potential cash cows. The commodification of nature and its protection has thus also arrived in Russia, albeit in a peculiar interpretation.

Against this background, this contribution explores how changing political and economic regimes have impacted Russian protected areas. In picking this focus, it thus continues in the tradition of political ecology, which BLAIKIE/ BROOKFIELD (1987, 17) once described as a combination of "the concerns of ecology and a broadly defined political economy" (cf. also BlaikIE 1999; KRINGS 2008). Examining the Russian system of protected areas as a whole, it complements those studies that have examined the political ecology of protected areas in other post-Soviet countries (e.g. SCHMIDT 2013), often with detailed case studies focusing on single sites (e.g. SCHMIDT/Doerre 2011).

The article traces the historical development of the protected areas network from its beginnings in the early Soviet period, but places particular emphasis on the incisive changes since the late 1980 s and then the 2000s as the period which has seen increasing stress on the economic valuation and valorisation of nature protection. This has gone lockstep with the transformation of the Russian political economy. After a period of state weakness and economic distress in the 1990s, which led to the emergence of diverse economies and alternative forms of social organisation beyond the state (SMith/Stenning 2006), the reassertion of state power under president $\mathrm{Pu}$ tin from the 2000s onwards refocused attention on central-state-led development and economic growth through resource exploitation (ROBINSON 2013). Environmental concerns were relegated to the sidelines of Russian politics (MoL 2009). The new political-ecological regime that has been emerging over the past years holds both opportunities and threats for the Russian reserves. It can bolster the income to fund operations for some reserves, while threatening to compromise conservation in favour of development. What makes it interesting from a geographical point of view is its uneven spatial impact, which is set to lead to rising territorial differentiation among protected areas.

\section{From sacred commandment to econo- mic exploitation: protected areas in the Soviet period}

As the largest landmass of any country - almost one-eighth of the planet's total - the territory of Russia covers a plethora of biomes and habitats. $22 \%$ of the world's forests are in Russia, with more than $30 \%$ being primeval forests (FAO 2005). Lake Baikal alone contains more than one-fifth of the world's fresh water sources. Rare and endangered mammals such as the Siberian tiger (Panthera tigris altaica), the Amur leopard (Panthera pardus orientalis), the snow leopard (Uncia uncia) and the Saiga antelope (Saiga tatarica) are encountered on Russian territory. This natural richness presents both a great opportunity but also a great responsibility for protection.

The first impulse for the designation of protection zones in Russia, however, was economic. Hunting and trapping of sable (Martes zibellina) was unbridled in late Tsarist Russia and had reached epidemic proportions. Nicknamed the 'soft gold of Russia', the fur of the sable drew hunters to the remotest regions of Siberia and the Russian Far East. The first Nature Reserve Barguzinskij Zapovednik (No. 1 in Fig. 1) on Lake Baikal was established in 1916 to protect the sable from extinction and allow a recovery of the population for further, more sustainable harvesting. The term for a strict nature reserve according to IUCN (International Union for Conservation of Nature) category Ia/b - zapovednik - is derived from the Russian word for the biblical commandments: заповедb. The connotations flowing from this choice of wording are not 
Fig. 1: Protected areas in Russia

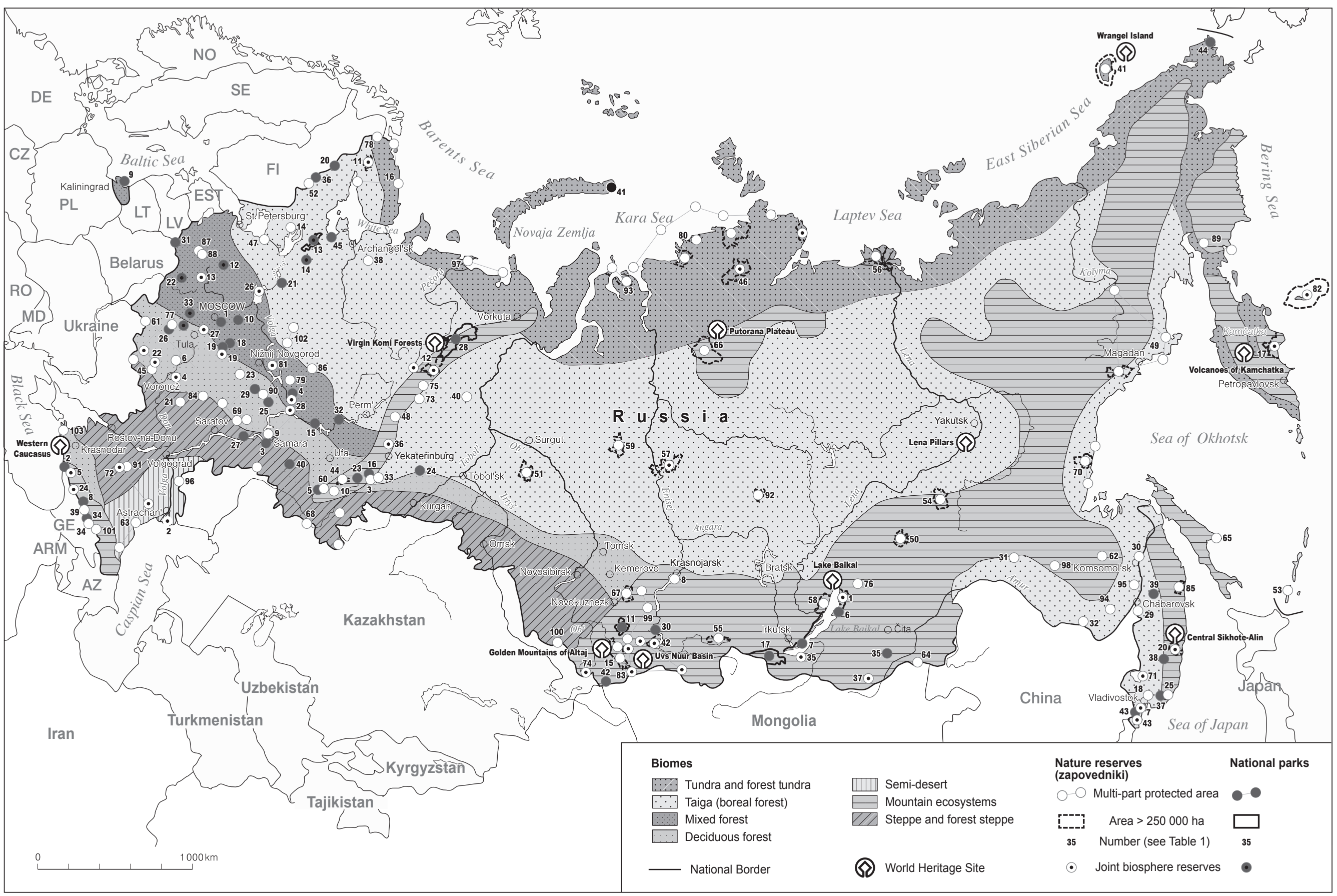

Source: www.forestforum.ru; Osteuropa 4-5/2008. Cartography: S. Dutzmann / W. Weber, update 2013. Leipzig, 2008. 

Tab. 1: Protected Areas in Russia (Protected areas in italics are also UNESCO biosphere reserves)

Zapovedniki (Nature Reserves, IUCN Category I)

Name Estab- Area Administrative lished (1000 ha) Unit

\begin{tabular}{|c|c|c|c|c|}
\hline 1 & Barguzinskij & 1916 & 374.3 & $\begin{array}{l}\text { Respublika Burja- } \\
\text { tija }\end{array}$ \\
\hline 2 & Astrachanskij & 1919 & 67.9 & Astrachanskaja \\
\hline 3 & Il'menskij & 1920 & 34.1 & Čeljabinskaja \\
\hline 4 & Voronežskij & 1923 & 31.1 & $\begin{array}{l}\text { Voronežskaja, } \\
\text { Lipeckaja }\end{array}$ \\
\hline 5 & Kavkazskij & 1924 & 280.3 & $\begin{array}{l}\text { Krasnodarskij } \\
\text { kraj, Adygeja, } \\
\text { Karačaevo- } \\
\text { Čerkessija }\end{array}$ \\
\hline 6 & Galič’ja gora & 1925 & 0.2 & Lipeckaja \\
\hline 7 & Kedrovaja Pad' & 1925 & 17.9 & Primorskij Kraj \\
\hline 8 & Stolby & 1925 & 47.2 & Krasnojarskij Kraj \\
\hline 9 & Žigulëvskij & 1927 & 23.2 & Samarskaja \\
\hline 10 & Baškirskij & 1930 & 49.6 & $\begin{array}{l}\text { Respublika } \\
\text { Baškortostan }\end{array}$ \\
\hline 11 & Laplandskij & 1930 & 178.4 & Murmanskaja \\
\hline 12 & Pečoro-Ilyčskij & 1930 & 721.3 & Respublika Komi \\
\hline 13 & Central'no-Lesnoj & 1930 & 24.4 & Tverskaja \\
\hline 14 & Kivač & 1931 & 10.9 & $\begin{array}{l}\text { Respublika Kare- } \\
\text { lija }\end{array}$ \\
\hline 15 & Altajskij & 1932 & 881.2 & Respublika Altaj \\
\hline 16 & Kandalakšskij & 1932 & 70.5 & Murmanskaja \\
\hline 17 & Kronockij & 1934 & 1142.1 & Kamčatskij Kraj \\
\hline 18 & Ussurijskij & 1934 & 40.4 & Primorskij Kraj \\
\hline 19 & Okskij & 1935 & 55.7 & Rjazanskaja \\
\hline 20 & Sichoté-Alinskij & 1935 & 401.4 & Primorskij Kraj \\
\hline 21 & Chopërskij & 1935 & 16.2 & Voronežskaja \\
\hline 22 & $\begin{array}{l}\text { Central'no- } \\
\text { Černozëmnyj }\end{array}$ & 1935 & 5.3 & Kurskaja \\
\hline 23 & Mordovskij & 1936 & 32.1 & $\begin{array}{l}\text { Respublika Mor- } \\
\text { dovija }\end{array}$ \\
\hline 24 & Teberdinskij & 1936 & 85.1 & $\begin{array}{l}\text { Karačaevo- } \\
\text { Čerkessija }\end{array}$ \\
\hline 25 & Lazovskij & 1940 & 121.0 & Primorskij Kraj \\
\hline 26 & Darvinskij & 1945 & 112.7 & $\begin{array}{l}\text { Vologodskaja, } \\
\text { Jaroslavskaja }\end{array}$ \\
\hline 27 & $\begin{array}{l}\text { Prioksko-Terras- } \\
\text { nyj }\end{array}$ & 1945 & 4.9 & Moskovskaja \\
\hline 28 & Volžsko-Kamskij & 1960 & 10.1 & $\begin{array}{l}\text { Respublika Tatar- } \\
\text { stan }\end{array}$ \\
\hline 29 & $\begin{array}{l}\text { Bol'šechech- } \\
\text { cirskij }\end{array}$ & 1963 & 45.4 & Chabarovskij Kraj \\
\hline 30 & Komsomol'skij & 1963 & 64.4 & Chabarovskij Kraj \\
\hline 31 & Zejskij & 1963 & 99.4 & Amurskaja \\
\hline 32 & Chinganskij & 1963 & 97.1 & Amurskaja \\
\hline 33 & $\begin{array}{l}\text { Vostočno- } \\
\text { Ural'skij }\end{array}$ & 1966 & 16.6 & Čeljabinskaja \\
\hline 34 & Severo-Osetinskij & 1967 & 29.5 & $\begin{array}{l}\text { Respublika Sever- } \\
\text { naja Osetija }\end{array}$ \\
\hline 35 & Bajkal'skij & 1969 & 165.7 & $\begin{array}{l}\text { Respublika Burja- } \\
\text { tija }\end{array}$ \\
\hline 36 & Visimskij & 1971 & 33.5 & Sverdlovskaja \\
\hline 37 & Sochondinskij & 1973 & 211.0 & Čitinskaja \\
\hline 38 & Pinežskij & 1974 & 51.5 & Archangelskaja \\
\hline 39 & $\begin{array}{l}\text { Kabardino-Bal- } \\
\text { karskij Vysoko- } \\
\text { gornyj }\end{array}$ & 1976 & 82.6 & $\begin{array}{l}\text { Kabardino-Bal- } \\
\text { karskaja Respub- } \\
\text { lika }\end{array}$ \\
\hline
\end{tabular}

40 Malaja Sos'va $1976 \quad 225.6$ Chanty-Mansijs-

41 Ostrov Vrangelja $19762225.7 \quad \begin{array}{ll}\text { Cukotskij AO } \\ \text { Cij AO }\end{array}$

42 Sajano-Šušenskij $1976 \quad 390.4 \quad$ Krasnojarskij Kraj

43 Dal'nevostočnyj $1978 \quad 64.3$ Primorskij Kraj Morskoj

44 Južno-Ural'skij 1978252.8 Baškortostan,

45 Belogor'e $\quad 1979 \quad 2.1 \quad$ Belgorodskaja

46 Tajmyrskij $\quad 19791781.9$ Krasnojarskij Kraj

47 Nižne-Svirskij $1980 \quad 41.6 \quad$ Leningradskaja

48 Basegi $\quad 1982 \quad 38.0$ Permskaja

49 Magadanskij $\quad 1982 \quad 883.8$ Magadanskaja

50 Vitimskij $\quad 1982 \quad 585.0 \quad$ Irkutskaja

51 Juganskij $\quad 1982 \quad 648.6$ Chanty-Mansijskij AO

52 Kostomukšskij $1983 \quad 47.6$ Respublika Kare-

53 Kuril'skij $\quad 1984 \quad 65.4 \quad$\begin{tabular}{ll} 
Sachalinskaja \\
\hline
\end{tabular}

54 Olëkminskij $\quad 1984 \quad 847.1$ Respublika Sacha (Jakutija)

55 Azas

56 Ust'-Lenskij

57 Central' nosibirskij

58 Bajkalo-Lenskij $1986 \quad 659.9$ Irkutskaja

59 Verchne-Tazovs- $1986 \quad 631.3$ Jamalo-Neneckij kij

60 Šul'gan-Taš $\quad 1986 \quad 22.5$ Respublika

61 Brjanskij les $1987 \quad 12.2$ Baškortostan

Brjanskaja

62 Bureinskij $\quad 1987 \quad 358.4$ Chabarovskij Kraj

63 Dagestanskij $1987 \quad 19.1$ Respublika Dage-

64 Daurskij $\quad 1987 \quad 45.8$ Čitinskaja

65 Poronajskij $\quad 1988 \quad 56.7$ Sachalinskaja

66 Putoranskij $1988 \quad 1887.3$ Krasnojarskij Kraj

67 Kuzneckij Alatau $1989 \quad 412.9$ Kemerovskaja

68 Orenburgskij $\quad 1989 \quad 21.7$ Orenburgskaja

69 Privolžskaja $\quad 1989 \quad 8.3$ Penzenskaja

Lesostep'

70 Džugdžurskij

71 Chankajskij

72 Černye Zemli

$1990 \quad 860.0 \quad$ Chabarovskij Kraj

$1990 \quad 39.3 \quad$ Primorskij Kraj

1990121.9 Respublika Kalmykija

73 Denežkin Kamen' $1991 \quad 78.2$ Sverdlovskaja

74 Katunskij $\quad 1991 \quad 151.6 \quad$ Respublika Altaj

75 Višerskij $\quad 1991 \quad 241.2$ Permskaja

76 Džerginskij $\quad 1992238.1$ Respublika Burjatija

77 Kalužskie Zaseki $1992 \quad 18.5$ Kalužskaja

78 Pasvik $1992 \quad 14.7$ Murmanskaja

79 Bol’šaja Kokšaga $1993 \quad 21.6$ Respublika Marij

80 Bol'šoj

Arktičeskij

81 Kerženskij

82 Komandorskij

83 Ubsunurskaja Kotlovina
Èl

19934169.2 Krasnojarskij Kraj

$1993 \quad 46.8 \quad$ Nižegorodskaja

19933648.7 Kamčatskij Kraj

$1993 \quad 323.2$ Respublika Tyva 


\begin{tabular}{|c|c|c|c|c|}
\hline 84 & Voroninskij & 1994 & 10.3 & Tambovskaja \\
\hline 85 & Botčinskij & 1994 & 267.4 & Chabarovskij Kraj \\
\hline 86 & Nurguš & 1994 & 5.9 & Kirovskaja \\
\hline 87 & Polistovskij & 1994 & 38.0 & Pskovskaja \\
\hline 88 & Rdejskij & 1994 & 36.9 & Novgorodskaja \\
\hline 89 & Korjakskij & 1995 & 327.2 & Kamčatskij Kraj \\
\hline 90 & Prisurskij & 1995 & 9.1 & $\begin{array}{l}\text { Čuvašskaja Res- } \\
\text { publika }\end{array}$ \\
\hline 91 & Rostovskij & 1995 & 9.5 & Rostovskaja \\
\hline 92 & Tungusskij & 1995 & 296.6 & Krasnojarskij Kraj \\
\hline 93 & Gydanskij & 1996 & 878.2 & $\begin{array}{l}\text { Jamalo-Neneckij } \\
\text { AO }\end{array}$ \\
\hline 94 & Bastak & 1997 & 91.8 & Evrejskaja AO \\
\hline 95 & Bolon'skij & 1997 & 103.6 & Chabarovskij Kraj \\
\hline 96 & $\begin{array}{l}\text { Bogdinsko- } \\
\text { Baskunčakskij }\end{array}$ & 1997 & 18.5 & Astrachanskaja \\
\hline 97 & Neneckij & 1997 & 313.4 & $\begin{array}{l}\text { Jamalo-Neneckij } \\
\text { AO }\end{array}$ \\
\hline 98 & Norskij & 1998 & 211.2 & Amurskaja \\
\hline 99 & Chakasskij & 1999 & 267.6 & $\begin{array}{l}\text { Respublika Cha- } \\
\text { kasija }\end{array}$ \\
\hline 100 & Tigirekskij & 1999 & 40.7 & Altajskij Kraj \\
\hline 101 & Ėrzi & 2000 & 6.0 & $\begin{array}{l}\text { Respublika } \\
\text { Ingušetija }\end{array}$ \\
\hline 102 & Kologrivskij Les & 2006 & 58.9 & Kostromskaja \\
\hline 103 & Utriš & 2010 & 10.0 & $\begin{array}{l}\text { Krasnodarskij } \\
\text { Kraj }\end{array}$ \\
\hline
\end{tabular}

National Parks (IUCN Category II)

\begin{tabular}{|c|c|c|c|c|}
\hline & Name & $\begin{array}{l}\text { Estab- } \\
\text { lished }\end{array}$ & $\begin{array}{c}\text { Area } \\
(1000 \mathrm{ha})\end{array}$ & $\begin{array}{l}\text { Administrative } \\
\text { ) Unit }\end{array}$ \\
\hline 1 & Losinyj Ostrov & 1983 & 12.9 & $\begin{array}{l}\text { Moscow, Mos- } \\
\text { kovskaja }\end{array}$ \\
\hline 2 & Sočinskij & 1983 & 193.7 & $\begin{array}{l}\text { Krasnodarskij } \\
\text { Kraj }\end{array}$ \\
\hline 3 & Samarskaja Luka & 1984 & 127.2 & Samarskaja \\
\hline 4 & Marij Čodra & 1985 & 36.6 & $\begin{array}{l}\text { Respublika Marij } \\
\text { Él }\end{array}$ \\
\hline 5 & Baškirija & 1986 & 82.3 & $\begin{array}{l}\text { Respublika } \\
\text { Baškortostan }\end{array}$ \\
\hline 6 & Zabajkal'skij & 1986 & 267.2 & $\begin{array}{l}\text { Respublika Burja- } \\
\text { tija }\end{array}$ \\
\hline 7 & Pribajkal'skij & 1986 & 418.0 & Irkutskaja \\
\hline 8 & Prièl'brus'e & 1986 & 101.2 & $\begin{array}{l}\text { Kabardino-Bal- } \\
\text { karskaja Respub- } \\
\text { lika. }\end{array}$ \\
\hline 9 & Kuršskaja Kosa & 1987 & 6.6 & Kaliningradskaja \\
\hline 10 & Pleščeevo Ozero & 1988 & 23.6 & Jaroslavskaja \\
\hline 11 & Šorskij & 1989 & 413.8 & Kemerovskaja \\
\hline 12 & Valdajskij & 1990 & 158.5 & Novgorodskaja \\
\hline 13 & Vodlozerskij & 1991 & 468.9 & $\begin{array}{l}\text { Karelija, } \\
\text { Archangel'skaja }\end{array}$ \\
\hline 14 & Kenozerskij & 1991 & 139.7 & Archangel'skaja \\
\hline 15 & Nižnjaja Kama & 1991 & 26.6 & $\begin{array}{l}\text { Respublika Tatar- } \\
\text { stan }\end{array}$ \\
\hline 16 & Taganaj & 1991 & 56.8 & Čeljabinskaja \\
\hline 17 & Tunkinskij & 1991 & 1183.7 & $\begin{array}{l}\text { Respublika Burja- } \\
\text { tija }\end{array}$ \\
\hline 18 & Meščera & 1992 & 118.9 & Vladimirskaja \\
\hline 19 & Meščerskij & 1992 & 103.0 & Rjazanskaja \\
\hline
\end{tabular}

20 Paanajarvi

21 Russkij Sever

22 Smolenskoe Poozer'e

23 Zjuratkul'

24 Pripyšminskie Bory

25 Čavaš Varmane

26 Orlovskoe

Poles'e

27 Chvalynskij

28 Jugyd va

29 Smol'nyj

30 Šušenskij Bor

31 Sebežskij

32 Nečkinskij

33 Ugra

34 Alanija

35 Alchanaj

36 Kaleval'skij

37 Zov Tigra

38 Udègejskaja Legenda

39 Anjujskij

40 Buzulukskij Bor

41 Russkaja Arktika

42 Sajljugemskij

43 Zemlja Leoparda

44 Beringija

45 Onežskoe Pomor'e
1992104.5 Respublika Karelija

1992166.4 Vologodskaja

1992146.2 Smolenskaja

$1993 \quad 88.2$ Čeljabinskaja

199348.7 Sverdlovskaja

199325.2 Čuvašskaja Respublika

$1994 \quad 77.7$ Orlovskaja

$1994 \quad 25.5 \quad$ Saratovskaja

19941891.7 Respublika Komi

199536.4 Respublika Mordovija

$1995 \quad 39.2 \quad$ Krasnojarskij Kraj

$1996 \quad 50.0 \quad$ Pskovskaja

199720.8 Udmurtskaja Respublika

199798.6 Kalužskaja

$1998 \quad 54.9 \quad$ Severnaja Osetija

1999138.2 Čitinskaja

200674.4 Respublika Karelija

$2007 \quad 82.2$ Primorskij Kraj

$2007 \quad 88.6$ Charabovskij Kraj

$2007 \quad 429.7$ Charabovskij Kraj

2008106.8 Orenburgskaja/ Samarskaja

20091426.0 Archangel'skaja $2010 \quad 118.3 \quad$ Respublika Altaj $2012 \quad 261.9$ Primorskij Kraj 20131819.4 Čukotskij AO 2013201.6 Archangel'skaja

UNESCO Natural World Heritage Sites

\begin{tabular}{|c|c|c|c|}
\hline & Name & Included & $\begin{array}{l}\text { Administrative } \\
\text { Unit }\end{array}$ \\
\hline 1 & $\begin{array}{l}\text { Virgin Komi } \\
\text { Forests }\end{array}$ & 1995 & Respublika Komi \\
\hline 2 & Lake Baikal & 1996 & $\begin{array}{l}\text { Irkutskaja, Res- } \\
\text { publika Burjatija }\end{array}$ \\
\hline 3 & $\begin{array}{l}\text { Volcanoes of } \\
\text { Kamchatka }\end{array}$ & 1996 & Kamčatskaja \\
\hline 4 & $\begin{array}{l}\text { Golden Moun- } \\
\text { tains of Altaj }\end{array}$ & 1998 & Respublika Altaj \\
\hline 5 & $\begin{array}{l}\text { Western } \\
\text { Caucasus }\end{array}$ & 1999 & $\begin{array}{l}\text { Krasnodarskij } \\
\text { Kraj }\end{array}$ \\
\hline 6 & $\begin{array}{l}\text { Central } \\
\text { Sikhote-Alin }\end{array}$ & 2001 & Primorskij Kraj \\
\hline 7 & Uvs Nuur Basin & 2003 & $\begin{array}{l}\text { Respublika Tyva } \\
\text { (and Mongolia) }\end{array}$ \\
\hline 8 & Wrangel Island & 2004 & Čukotskij AO \\
\hline 9 & Putorana Plateau & 2010 & Krasnojarskij Kraj \\
\hline 10 & Lena Pillars & 2012 & $\begin{array}{l}\text { Respublika Sacha } \\
\text { (Jakutija) }\end{array}$ \\
\hline
\end{tabular}


coincidental: protection in the zapovedniki is to be obeyed as strictly as biblical commandments and nature in the zapovedniki is placed beyond human interference (WEINER 1988). As such, zapovedniki became veritable sancta of nature with a complete ban on visitation and economic exploitation.

The centralised communist state with complete state ownership of land and the power of administrative fiat provided favourable conditions for enforcing a strict protection regime. The remoteness of most reserves facilitated the implementation of this ban. It remained the prerogative of scientists to enter zapovedniki for ecological monitoring. As indicators of nature (étalony prirody) and models of unspoilt wilderness, zapovedniki started to supply and continue to supply until today unparalleled time series data across a broad spectrum of ecological variables. For scientists, zapovedniki were what WEINER (1999) calls an "archipelago of freedom". Tucked away in the remote corners of the country, they provided a refuge from the repressions of the Stalinist era. Under the guise of scientific progress, scientists even pushed boldly for setting aside further tracts of land and managed to expand the zapovednik system in Russia to a total of more than $10 \mathrm{~m}$ ha until the early $1950 \mathrm{~s}$.

Yet, the sacred status of zapovedniki did not last for long. As Stalin stepped up his efforts of industrialisation, the exploitation of nature followed suit. Emblematic is the Great Plan for the Transformation of Nature, decreed in 1948, which envisioned massive agricultural and land improvement projects such as irrigation works. As a consequence, the role of the zapovedniki and the scientific research in them underwent a revaluation. Now considered a hamstring to the appropriation of nature, in particular the expansion of forestry, the number and size of the zapovedniki was axed in an act from 1951 (Postanovlenie 3192 Soveta Ministrov). It reduced the total area of zapovedniki in the Soviet Union to one-tenth and closed 88 out of 128 of them, dropping from an area of 12.6 to a mere 1.4 $\mathrm{m}$ ha (LARIN et al. 2003, 17). Ecological research and monitoring were increasingly meant to serve the purposes of industrialisation and reserves became an "area in which scientists would learn to master and transform nature to serve the needs of the economy" (NEwell 2004, 35).

Perhaps the most grotesque example of the enmeshment of industrialisation and conservation can be found in the Eastern Urals Zapovednik, which was designated after the Kyshtym disaster in 1957, the third largest nuclear incident after Chernobyl and Fukushima. It continues to operate today under the auspices of the Russian $\mathrm{Nu}$ clear Authority (Rosatom), to measure the impact of radioactive fall-out on the surrounding environment. Although Stalin's death led to a reversal of a large number of the policies he had initiated, the gradual re-establishment of the zapovedniki was an arduous task whose accomplishment was due, in large part, to the tenacity and dedication of Soviet scientists (WEINER 1999). It was only in 1985 that the size of the area under protection again reached the level of 1951 .

\section{Liberalism: Expansion in the 1990s}

The perestroika under Gorbačëv foreshadowed some of the developments that became characteristic of the 1990s after the collapse of the Soviet Union: a renewed emphasis on environmental protection and nature conservation, which shifted the balance back from exploitation to protection. From the mid-1980s, plans were voiced to establish a unified state authority in charge of nature protection. This culminated in the formation of the State Committee for Nature Protection (Goskomprirody) in 1988, which also took charge of the zapovedniki. The same year saw the foundation of what was to become Russia's strongest and most influential environmental NGO, the Socio-Ecological Union, which turned into the nexus and voice of citizens' environmental concerns.

When the Soviet Union dissolved in 1991, two favourable factors created a window of opportunity for conservationists. One was the political vacuum and fragile state power of the 1990s, which allowed domestic and international NGOs as well as international governmental organisations to step in and environmental concerns to gain considerable momentum. Large international NGOs opened offices in Russia in the 1990s, including Greenpeace (1992), the Worldwide Fund for Nature (WWF) (1994) and the Green Cross (1994), and started to channel funding into conservation projects as well as raise international awareness for environmental issues in Russia. Helping the conservation impetus, the successor of the State Committee for Nature Protection (Goskomékologija) received considerable autonomy in decision-making with regard to environmental issues. 
The other favourable factor was the economic collapse, which reduced ambitions for development activities on wild lands and made them available for conservation. A presidential decree from 1992 (Ukaz 1155) made the designation of new protected areas a priority task of governmental environmental policy and set the goal to allot $3 \%$ of Russia's terrestrial area to zapovedniki and national parks. That meant more than doubling the existing area under strict protection. In the absence of funds from the state budget, the government sought to attract funding from abroad. The Global Environment Facility (GEF), for example, has awarded more than 300 m US\$ in project funding to Russia since 1991, leveraging in excess of 2 bn US\$ through cofinancing (GEF 2012). Bilateral donors such as the United States through USAID or Germany through its Federal Agency for Nature Conservation $(\mathrm{BfN})$ and Kreditanstalt für Wiederaufbau (KfW) have also provided funds, in particular during the transition period of the 1990s. In some instances where the Russian state could not be moved to establish a protection regime for a particular territory, private long-term leases of land were arranged. This was the case for the Murav'ëvka Park, which was established through a private gift of 50000 US\$ from a Japanese manufacturer, channeled through the Socio-Ecological Union and invested into a 50 -year lease of 5206 ha of land in the Russian Far East (HerRold-MENZIES 2012). However, this trend towards private reserves did not catch on to a larger extent.

In short, the lack of funds as well as the weakness of the Russian state in the 1990s attracted a plethora of actors as well as financing from different sources that sought to expand the protected area network. In particular, private funds flowed into conservation, supplementing or indeed taking over to a large degree from the statefinanced model. Yet, what distinguished it from the trend towards neoliberal conservation we are seeing today was the absence of monetary valuation and of expected monetary pay-offs. Nature was not regarded as a capital to be auctioned off, traded and exchanged or to reap returns on, but rather as something worth protecting in its own right.

What resulted from this window of opportunity in the 1990s was a veritable rallye of designations of new protected areas. From the collapse of the Soviet Union in December 1991 until 1999, 25 new zapovedniki and 18 new national parks were designated, increasing the total area thus protected from 26 to $41 \mathrm{~m}$ ha - about $2.4 \%$ of Russia's terrestrial area (see Fig. 2). In 1995, a new Law on Protected Areas provided the legal foundations for territorial conservation in Russia (cf. Ostergren 2001). It defined a Russian umbrella term for protected areas - Osobo Ochranjaemye Prirodnye Territorii (OOPT) - and different categories that follow loosely the IUCN classification (see Tab. 2). At the federal level, there are three major types of reserves.

1) Zapovedniki as the flagship of Russian territorial conservation with the highest protection status and minimal intervention (similar to IUCN category I). Zapovedniki are designated on the basis of natural conservation criteria and reserved for ecological research and monitoring.

2) National Parks, serving protection, research, education and tourism through differential zoning (similar to IUCN category II). National parks can protect areas of significant natural as well as historic and cultural value.

3) Zakazniki as areas with restricted land use for the protection of landscapes or special biological, paleontological, hydrological or geological features (similar to IUCN category IV and VI). Since their protection status is less strict, zakazniki are typically not considered on a par with zapovedniki and national parks when it comes to conservation.

The liberal spirit of the Law on Protected Areas manifested itself in two major changes in the protection regime. First, the law accorded protected areas wide-ranging operational autonomies in the achievement of their tasks and curtailed the possibilities of federal tutelage from Moscow. This move provided the reserves with new freedoms, among others also to levy fines and develop new revenue streams, such as nature-based tourism, and to collect the proceeds from them. It corresponded to the political economy of the transition reforms with their emphasis on decentralisation and deregulation, but also reflected the economic exigencies of the time, where federal alimentation of protected areas was all but absent and alternative revenue sources had to be tapped.

Second, the law also aimed to embed protected areas more into society through mandating environmental education, tourism and public partici- 
Tab 2: Characteristics of the most important types of protected areas in Russia

\begin{tabular}{|c|c|c|c|c|c|}
\hline Russian nomenclature & Zapovednik & Nacional'nyj Park & Pamjatnik Prirody & Zakaznik & Prirodnyj Park \\
\hline $\begin{array}{l}\text { International } \\
\text { nomenclature }\end{array}$ & $\begin{array}{c}\text { Strict Nature } \\
\text { Reserve / } \\
\text { Wilderness Area }\end{array}$ & $\begin{array}{l}\text { National } \\
\text { Park }\end{array}$ & $\begin{array}{c}\text { Natural } \\
\text { Monument }\end{array}$ & $\begin{array}{c}\text { Habitat / } \\
\text { Species Manage- } \\
\text { ment Area }\end{array}$ & $\begin{array}{l}\text { Protected } \\
\text { Landscape }\end{array}$ \\
\hline IUCN category & $\mathrm{Ia} / \mathrm{Ib}$ & II & III & IV or VI & V \\
\hline \multicolumn{6}{|c|}{ Objectives (in Russia / according to IUCN) } \\
\hline Conservation & $+/+$ & $\mathrm{o} /+$ & $0 / 0$ & $0 / 0$ & $\mathrm{o} / \mathrm{o}$ \\
\hline Research & $+/+$ & $0 / 0$ & $-/ 0$ & $0 / 0$ & $0 / 0$ \\
\hline Education & $+1-$ & $+/ 0$ & $\mathrm{o} / \mathrm{o}$ & $0 / 0$ & $\mathrm{o} / \mathrm{o}$ \\
\hline Tourism & $\mathrm{o} /-$ & $+1+$ & $\mathrm{o} /+$ & $\mathrm{o} / \mathrm{o}$ & $+1+$ \\
\hline Sustainable land use & $-1-$ & $\mathrm{o} / \mathrm{o}$ & $-1-$ & $\mathrm{o} /+$ & $-/ 0$ \\
\hline Administrative level & Federation & Federation & Subjects & $\begin{array}{l}\text { Federation and } \\
\text { subjects }\end{array}$ & Subjects \\
\hline Number & 103 & 44 & ca. 7500 & 70 and ca. 3000 & ca. 50 \\
\hline Staff (per area) & 40 to 80 & 120 & - & - & - \\
\hline Total area (million ha) & 33.8 & 11.4 & ca. 3.2 & 12.7 and ca. 157.5 & $\mathrm{n} / \mathrm{a}$ \\
\hline Average area (1000 ha) & 340 & ca. 180 & $\max .0 .5$ & ca. 57 & $\mathrm{n} / \mathrm{a}$ \\
\hline $\begin{array}{l}\text { Proportion of total } \\
\text { land area }\end{array}$ & $1.6 \%$ & $0.7 \%$ & $0.2 \%$ & $0.7 \%$ and ca. $9.3 \%$ & $\mathrm{n} / \mathrm{a}$ \\
\hline $\begin{array}{l}\text { Number of } \\
\text { biosphere reserves }\end{array}$ & 34 & 5 & 0 & 0 & 0 \\
\hline
\end{tabular}

$+=$ Primary objective $\quad 0=$ Secondary objective $-=$ No objective

Current as of December 2013

Sources: Russian Ministry of Natural Resources; www.oopt.info; LARIN et al. 2003

pation as crucial pillars. The idea behind this was to generate public awareness of nature conservation and increase the legitimacy of protected areas in local communities. This grew from the realisation that all too often protected areas had pursued fortress conservation approaches which had estranged local communities and led to protracted conflicts (MüLLER 2008, $427 \mathrm{f}$.), thus rather hamstringing than buttressing the cause of conservation. But the assumption was also that reaching out to the general public would ensure continued political and fiscal support for protected areas, as demonstrated in the United States, for example (OsTERgREN 2001). As a consequence of this opening up, new stakeholders - NGO, local residents, visitors - had to be incorporated into the management of protected areas, displacing some of the traditional authority of scientists (OSTERGREN/JACQUES 2002).

What compromised the unprecedented expansion and the new freedoms, was the economic hardship of Russia in the 1990s. While the number of protected areas multiplied, there were few funds for their operation. If salaries arrived at all, they arrived late. Often, protected areas management lacked the most basic supplies such as fuel for patrol vehicles and had to start subsistence agriculture for survival (SITTLER et al. 2000). This situation led to an exodus of qualified personnel as well as a much-reduced capacity to enforce the protection regime vis-à-vis violations. In forest biomes, some reserves resorted to logging to create revenue that would keep the operations running. Newly established reserves often remained 'paper reserves for several years, lacking even the most rudimentary basics such as an official staff or director' (OSTERGREN 2001, 148). At the same time, economic hardship and weak law enforcement meant that poaching and illegal logging became more and more common. In particular in the Far East, large consignments of round timber flowed from protected areas close to the border with China to supply Chinese furniture and flooring manufacturers. While protected areas had gained weight on paper, much remained to be done to turn them into effective organisations in practice. 


\section{Antagonism: de-ecologisation and development pressure in the $2000 \mathrm{~s}$}

Vladimir Putin's inauguration, however, ushered in a new turn in the political ecology of protected areas. Whereas in the 1990s nature protection was poor but had considerable political clout, in the 2000s the political weight shifted to resource exploitation as economic growth began to pick up and state-building proceeded apace. Russian protectionists speak of a period of "deecologisation" (deékologizacija) (LARIN et al. 2003,9). International donors and development organisations withdrew, as Russia turned from a net aid recipient into a net donor. The most incisive change happened in the spring of 2000, when Putin dissolved Goskomékologija and merged it into the pro-development Ministry of Natural Resources. This move severely curtailed the administrative weight of environmental protection: Goskomékologija's competencies were cut and staff were redistributed within the ministry. While zapovedniki and national parks were united under one roof for the first time, the agency in charge, Rosprirodnadzor, is understaffed and has limited decision-making power. For protected areas, decision-making is still fragmented. National parks in particular contain swathes of land with commercial agriculture and forestry or have settlements on their territories, so that other ministries continue to be involved in decision-making and protection goals are compromised.

This administrative degradation of environmental protection was reflected in the slashing of the goals for designating new protected areas as well as in the decline or complete halt of actual designations. While an order from 1994 (Rasporjaženie Pravitel'stva RF, 23 April 1994, No. 572-r) had mandated the creation of 72 new zapovedniki and 42 new national parks until 2005, an order from 2001 (Rasporjaženie Pravitel'stva RF, 23 May 2001, No. 725-r) instated much less ambitious goals: now, 9 zapovedniki and 12 national parks were to be created until 2010, i.e. 21 reserves instead of the original 91. In both cases, de facto designations fell far short of the self-imposed goals (see Fig. 2 ). In the 1990s financial limitations had not allowed to create more protected areas and in 1999 the Ministry of Finance had even vetoed new reserves due to a lack of funds. Since 2000, however, it was the Ministry of Natural Resources itself which held back the creation of new reserves through imposing additional bureaucratic obstacles and delaying procedures (STEPANICKIJ 2004). Nature protection was thus faced with the paradoxical situation that the authority in charge of it at the same time tried to obstruct it wherever possible. As a result, there were no new designations of reserves from 2001 to 2005 and only one new zapovednik was established in the period from 2001 to 2010 .

In general, economic development started to take precedence over conservation from the 2000s. Increasingly, state authorities began to see environmental protection as an obstacle to achieving economic growth. One indicator of this is the shift from zapovedniki to national parks in the designation of new protected areas since the beginning of the 2000s (see Fig. 2). National parks allow more options for development of activities besides conservation and the Ministry of Economic Development viewed them with less suspicion of obstructing economic growth than zapovedniki (STEPANICKIJ 2004). In the intended designations of new protected areas from 2011 to 2020 (Rasporjaženie Pravitel'stva RF, 22 December 2011, No. 2322-r), national parks outnumber zapovedniki two to one. The formal classification, however, often does not correspond to the conservation properties and de facto management of reserves. A recent study found, for example, that a large number of Russian national parks are more appropriate to IUCN category I, i.e. zapovedniki (KREVER et al. 2009, $38 \mathrm{ff}$.). Several reserves are thus operating under a less strict protection regime than would be adequate.

With economic growth taking off, development projects and conservation came to be at loggerheads more often. Mining, oil and gas exploration, commercial logging and tourism development have encroached on different protected areas. Among the most critical projects are several that threaten UNESCO World Heritage Sites. Accommodating gold mining activities in parts of the Jugyd-Va National Park (No. 28 in Fig. 1) in the Virgin Komi Forests, local authorities have attempted to extract the affected areas from the national park. In the Golden Mountains of Altai World Heritage Site, Gazprom has been planning to construct a pipeline across the Ukok plateau for exporting gas to China. Although plans were shelved in May 2013 in favour of an alternative route in the Far East, once again economic concerns related to Chinese demands and not ecological ones were the major drivers for this decision (Forbes 2012). 
Fig. 2: Development of the number and total area of federal protected areas in Russia

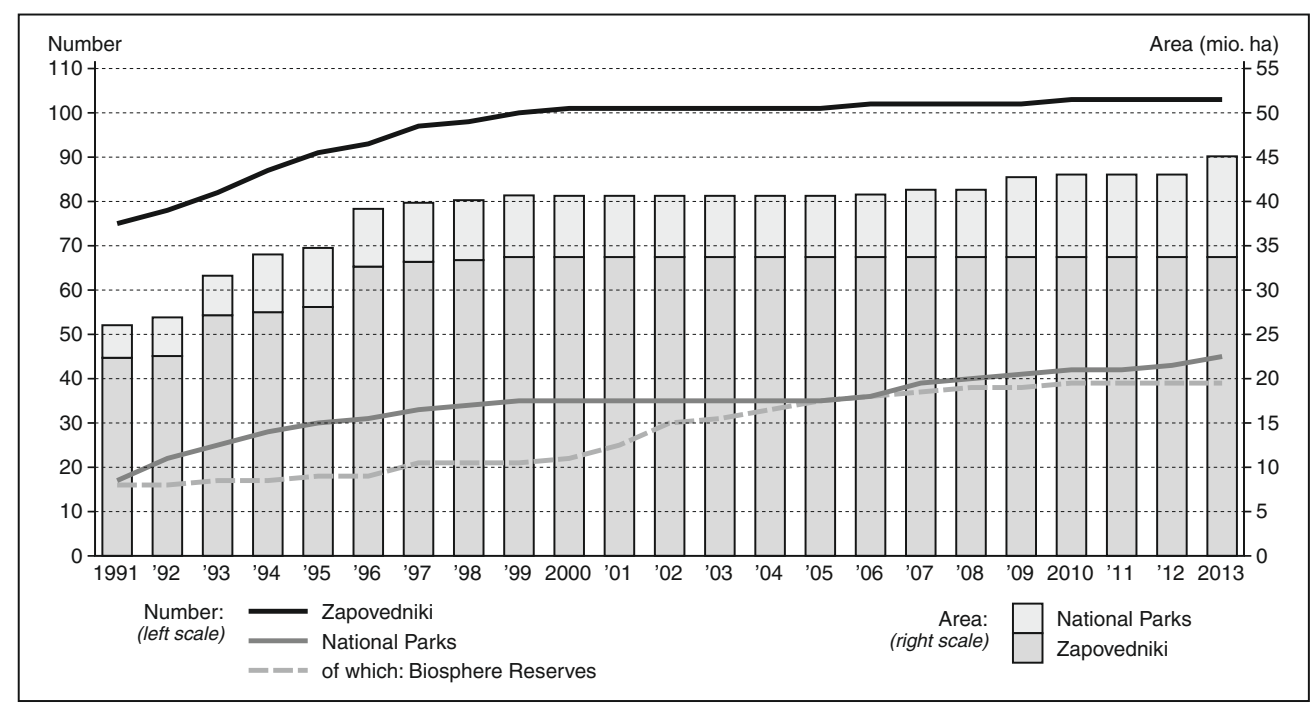

Sources: www.oopt.info; Ministry of Natural Resources

While reserves have come under growing development pressure in the 2000 s, what also increased was the budget lines. With the incorporation into the Ministry of Natural Resources in 2000 , the budget available for environmental protection more than doubled and it has since been growing more or less in pace with the federal budget (MÜLLER 2008). These increases have resulted in a paradoxical situation where protected areas have enjoyed an increase in funding with a concomitant decrease in political weight. It bears mentioning, however, that these budget increases added to a low base level, after the collapse of the Soviet Union had shrunk budgets of protected areas by as much as $90 \%$ in the 1990s (WeLls/WilLIAMS 1998, 200). Even now, an inspector in an average zapovednik earns no more than RUB 4000 (about $100 €$ ) per month (Greenpeace 2011). As a result, reserves are often unable to attract and retain qualified staff, but have to hire untrained personnel and invest extensively in their qualification. Having received this training, it is not uncommon, however, that people quit and apply for better paid jobs with their newly acquired skills (FIORINO/OSTERGREN 2012).

In 2009, the latest year for which data are available to the author, the total budget for the Russian zapovedniki and national parks was 2.7 bn roubles, about $62 \mathrm{~m} €$, for a total area of about
$43 \mathrm{~m}$ ha (see Fig. 2). For comparison, this is about six times the budget of Bavarian Forest National Park in Germany with an area of $0.024 \mathrm{~m}$ ha. While the lion's share of financing still comes from the federal budget, the second largest source of income are revenue-generating activities. In most cases, these are created either through timber harvesting or through tourism activities such as offering guided tours, accommodation or charging admission fees for parts of a reserve. The operating budget shows high variance between protected areas. In 2009, Tigirekskij Zapovednik (No. 100 in Fig. 1), for example, had to make do with RUB $6.5 \mathrm{~m}$ (about $150000 €)$ per year and its only additional income outside the federal budget was a small amount from foreign grants $(6500 €)$. Despite these financial restrictions, it has been able to develop a wide range of activities beyond environmental conservation, ranging from outreach and education to nature-based tourism in cooperation with local communities and cultural events such as a museum night. Sochi National Park (No. 2 in Fig. 1), by contrast, had an annual operating budget of $303 \mathrm{~m}$ roubles (about $7 \mathrm{~m} €$ ) and raked in more than half of it (179 m roubles) through revenue-generating activities. Almost half of the park's territory is designated as a recreational zone, and its proximity to the tourist hotspot of Sochi has allowed it to develop a wide range of activities for visitors. 
The political ecology of the 2000s thus experienced a shift in priorities away from increasing the area under protection to pursuing development activities which were often at odds with protection goals. Protected areas saw themselves increasingly faced with having to fend off attempts at using their territories. While the funding experienced significant augmentation, the designation of new protected areas was delayed and previous goals for new designations were revised downwards. Protected areas were forced to conclude compromises, as the pressure on them to open up to development was ratcheted up.

\section{Neoliberalism: economisation in the 2010s}

The stand-off between protection and development, characteristic for the $2000 \mathrm{~s}$, took a new turn in the 2010s. Whereas earlier protected areas would be perceived as an obstacle to be reduced or avoided, a gradual change of thinking started to see them more and more as an asset to create a potential return on investment. The 2011 order of the Russian government (Rasporjaženie Pravitel'stva RF, 22 December 2011, No. 2322-r) reflects this new take on protected areas. It mandates to pursue tourism development through building new infrastructure and establishing a unified brand of Russian protected areas. For that purpose, reserves are expected to attract investors and cooperate with international travel agencies. In order to kick start this economic valorisation, the Russian government provided seed funding of 2.4 bn roubles (ca $55 \mathrm{~m} €$ ) for the period from 2011 to 2013, which represents a top-up of about one-quarter of the annual budget for protected areas for that period. The basic idea is to leverage this seed financing to capitalise on the rapid increase in tourist flows. The Ministry of Natural Resources reported a jump in estimated visitor numbers from $0.89 \mathrm{~m}$ in 2004 to $1.6 \mathrm{~m}$ in 2006 and $6.5 \mathrm{~m}$ in 2010 and aims to attract $13 \mathrm{~m}$ visitors by 2013 (Moscow Times 2012, MülLER et al. 2011). In a move towards the commodification of protected areas, the ministry decided to start levying admission fees for protected areas from 2014 onwards. If each of the $13 \mathrm{~m}$ prospective visitors paid but 170 roubles (ca. $4 €$ ) in entrance fees, this would equal the federal budget for protected areas. Currently, Pribaikal'skij National Park (Nr. 7) is one of the few reserves to charge admissions fees, in this case at a rate of 60 roubles (ca. $1.50 €$ ) per adult per day.
The general idea of developing responsible nature-based tourism points to the willingness to enhance the economic use value of parks. Experience has shown that it can both create substantial revenue streams for local communities (MAYER et al. 2010) and enhance visitors' awareness of ecological issues, if well managed (EAGLES et al. 2002). Both of these fields need more attention in Russia. The local population has commonly perceived reserves as a nuisance, constraining rather than assisting them in their livelihoods. Rigorously enforced hunting, fishing, mushroom picking and visitation bans have done more to estrange the local population than to secure its support. The creation of new income sources through tourism provides the opportunity to increase local acceptance of reserves. This would help reduce conflicts and instances of local corruption as well as bolster law enforcement in the reserves if local authorities stand behind it. Ecological education and awareness, too, are in dire straits in Russia: Nature-based tourism in Russia, the great majority of which is domestic, often is a high-impact activity, where hunting, fishing and consuming play a major role, and littering is common (IAKOVLEVA et al. 2012). A concerted approach could create a model of sustainable tourism in reserves with potential educational effects on visitors that could lead to a behavioural change.

In its push to develop reserves, Russia has the United States in mind. In a 2010 cabinet meeting, Putin cited the US National Park Service (NPS) as a model: "Yellowstone National Park is visited by 2 million tourists [annually], while we in Kamchatka have only a few thousand people visiting per year" (Moscow Times 2012). A 2012 strategy paper of the Ministry of Natural Resources compares the figure of an alleged 14200 m US \$ of tourist revenues in the United States to a mere 11.7 m US\$ in Russia to justify the push for increased development (Rossijskaja Gazeta 2012). The explicit assumption is that protected areas can be turned into profitable ventures and cover their own costs in the future. This expectation ignores, however, that while the NPS created $337 \mathrm{~m}$ US\$ in revenues in 2012, it also had 2900 m US\$ in costs (National Park Service 2012)! Even in the United States, then, conservation continues to be an endeavour that requires significant public subsidies. In Russia, only a few reserves have the chance to become self-sustaining. These are either close to tourist centres and boast easy infrastructural access, such as Sochi National Park, or feature spectacular landscapes 
and mega-fauna, such as Kronockij Zapovednik in Kamčatka (No. 17) that Putin was referring to.

The current approach to valorising reserves in Russia, however, privileges revenue generation over ecological concerns in manifold ways. For one thing, most of the tourism development is scheduled to take place in the zapovedniki, which, as IUCN category I reserves, are not intended for tourism. Ten zapovedniki but only two national parks have been put forward to take part in a pioneer project for tourism development. Up to now, zapovedniki have been spared mass tourism development, but this might change with the clear disregard of areas' protection status in the rollout of this policy. Moreover, the government has threatened to freeze the financing for reserves that do not sign up for this policy. Several truculent reserve directors have been replaced with managers who are more eager to implement the government's plans (Moscow Times 2012). At stake here is what RoBBins (2012, 176ff.) has termed an issue of conservation and control: control is wrested from reserves and from local residents alike and conservation policies are imposed from the central state down. This applies a forteriori to the situation in Russia, with its dominance of vertical power relationships and the recentralisation since the 2000 s, where local concerns are even less of consideration than in most other countries. As tourism development is forced onto protected areas, criteria for what constitutes successful management are changing. Entrepreneurialism and creating revenue are becoming more important than biodiversity conservation or local livelihoods.

Because revenues from tourism enter the budget of the individual reserves directly and not that of the ministry, there is an immediate incentive to maximise revenue-generating activities - often to the detriment of nature. Although it would often be wiser to concentrate accommodation and leisure offerings outside the reserves so as to minimise the ecological impact, for example, this would also mean that the revenues would flow into the coffers of the municipalities and not of the reserve. Reserves are thus in direct competition with municipalities, which is intensified through the current skewed reward structure in favour of development. Selling permits for recreational activities such as rafting, hunting or fishing or for the use of motorised vehicles $(4 \times 4$, snow mobiles, ...) is another potential source of income, but again leads to an increase of undesirable forms of tourism. Given the absence of standards and regulations regarding eco-tourism as well as the lack of competencies and skills (IAKOVLEVA et al. 2012), developing sustainable eco-tourism seems to be a distant mirage for now.

For another, the balance between protection and use has clearly tipped towards the latter's side, when in November 2011 the Russian parliament passed amendments to the 1995 Law on Protected Areas, which facilitated the construction of sports facilities in protected areas. This decision presented the gravest pro-development legislation for protected areas in a long time. The occasion for this revision were multiple plans to construct ski resorts and recreation facilities in the Caucasus Mountains and along the Black Sea Coast, affecting protected areas such as the Caucasus Zapovednik (No. 5), the Utriš Zapovednik (No. 103) and Sochi National Park (No. 2). Among them, the 2014 Winter Olympics in Sochi on the Russian Black Sea coast were the highest profile venture, along with a string of seven further resorts in the North Caucasus. The developer OAO Northern Caucasus Resorts is pursuing this project, which envisions building $1100 \mathrm{~km}$ of ski runs and 140000 hotel beds for an expected $10 \mathrm{~m}$ annual visitors and at a price tag of 450 bn roubles (about 10 bn $€$ ) (JOHNSON 2012). The amendments constituted a compromise between developers and protectionists in face of the threat to downsize Sochi National Park to allow for construction of winter sports facilities (MÜLLER 2014). While such downsizing would have given over the excluded territory to privatisation, and thus up for grabs for both developers and state officials, under the new legislation the areas remain under the jurisdiction and ownership of the protected areas. Developers and protected areas have to agree on a long-term lease and the operation of the facilities must conform with ecological principles. This compromise enshrined the principle of the non-violability of reserve boundaries, while at the same time ceding ground to development interests.

Paired with lax regulation and oversight as well as a weak rule of law, as is the case in Russia, the race for development also creates ample opportunities for administrative rent-seeking. The relaxation of conservationist regulation afforded through the 2011 order must also be understood in this context: It provides a source of resource appropriation for state officials through turning protected lands into commodities. Because construction permits in reserves are coveted due 
to the privileged location, federal civil servants and reserve managers are able to extract kickbacks for allocating these permits, for example (MülLER et al. 2011). These opportunities to reap private gain are at odds with ecologically responsible development, since the highest kickbacks can be obtained for the least sustainable activities.

Granting concessions for reserve development to a small number of developers would be able to ameliorate some of these concerns. These developers would be responsible for running food, lodging or retail operations and could be monitored more easily and made to adhere to a basic set of sustainability and pricing principles. This is a model pursued in some major US national parks, where the company Xanterra has the concession to operate campsites, hotels and gift shops. Although the new development regime in Russia explicitly suggests such a privatised model, there have been no bids from interested investors so far. The remoteness of many reserves as well as the lack of basic transport infrastructure are formidable obstacles. The majority of reserves are several hours by plane and a subsequent lengthy overland drive from the closest international airport. Many of them cannot be accessed through road travel in regular vehicles or are off-limits during certain times of the year due to weather conditions.

The low level of service quality in the tourism sector and the lack of a stable rule of law, which is critical for investment decisions, do not help either. A report from the World Economic Forum placed Russia on rank 138 out of 140 as one of the least welcoming tourist destinations in the world (Blanke/Chiesa 2013). These factors keep entrepreneurs from investing into tourism infrastructure, because of the uncertainty involved. What continues to predominate is thus a piecemeal approach, in which reserves can launch their own tourism initiatives whose extent and compatibility with nature protection are a function of the directors' entrepreneurialism and moral integrity, the accessibility of the territory, the attractiveness of the natural endowment and the willingness to cooperate with local municipalities.

\section{Conclusion}

Political and economic processes have had tremendous impacts on protected areas in Russia, both in the Soviet and in the post-Soviet period. In this sense, reserves in Russia are not only, as they have always been, indicators of nature, but also indicators of the dominant political and economic regime. Any analysis of the governance and management of reserves must thus be sensitive to the links between the two. Since the collapse of the Soviet Union in 1991 one was able to observe a shift from a liberal political ecology in the 1990s to an antagonistic one in the 2000s and a neoliberal one taking hold since about 2010 (see Tab. 3 for a summary). During the liberal period, new protected areas mushroomed and new stakeholders appeared on the stage, as reserves opened up to the outside. As the Russian economy picked up in the 2000s, economic interests increasingly started to get into conflict with territorial protection. The designation of new areas came to a grinding halt and existing areas had to defend themselves against attempts at resource exploitation. The neoliberal period, then, no longer saw reserves as a barrier to growth but rather as potential assets to create a return on investment. The valorisation and commodification of areas' natural endowment started to occupy the top of the agenda, with new initiatives to boost tourism and raise entrance fees.

Yet, the neoliberal conservation logic - becoming more dominant worldwide - has taken hold in Russia with an important, almost perverse twist. While this shift has the potential to generate additional revenues for cash-strapped reserves and widen the possibilities for environmental outreach, it also carries a distinct risk of overdevelopment and overexploitation. All too often, the gradual commodification of nature in protected areas is not happening in the interest of conservation, but for the sake of creating a return on investment. Reserves are exhorted to turn a profit and develop entrepreneurial thinking to squeeze more revenues out of their territories. Neoliberal conservation is thus heading off in the wrong direction in Russia: economic incentives are not aligned with goals of nature conservation, as it should be. Rather, nature conservation must be adapted to the exigencies and demands of the markets. This new imperative creates uneven spatial impacts: reserves that are close to tourist hotspots, easily accessible, boast attractive landscapes or charismatic mega-fauna, have an entrepreneurial director and are willing to permit more recreational activities on their territories will thrive. Others that are remoter, have stricter protection policies or lack in natural attractiveness are likely to suffer. New desig- 
Tab. 3: The changing political-ecological regimes in Russia since the end of the 1980s

\begin{tabular}{|c|c|c|c|}
\hline Regime & Characteristics & Administrative Acts & Actor Groups \\
\hline $\begin{array}{l}\text { Liberalism } \\
\text { (late 1980s } \\
-1990 \mathrm{~s} \text { ) }\end{array}$ & $\begin{array}{l}\text { - 'Conservation bonanza': } \\
\text { designation of } 25 \text { new } \\
\text { zapovedniki (IUCN cate- } \\
\text { gory I) and } 18 \text { new national } \\
\text { parks (IUCN category II) } \\
\text { - Weakness of Russian state } \\
\text { - International and private } \\
\text { funding during budget cri- } \\
\text { sis after the Soviet collapse } \\
\text { - Expansion of mission of } \\
\text { protected areas to include } \\
\text { tourism, public participa- } \\
\text { tion and environmental } \\
\text { education } \\
\text { - International environmen- } \\
\text { tal NGOs (ENGOs) open } \\
\text { offices in Russia }\end{array}$ & $\begin{array}{l}\text { - 1988: Formation } \\
\text { of State Commit- } \\
\text { tee for Nature Pro- } \\
\text { tection (Goskom- } \\
\text { prirody) } \\
\text { - 1992: Order 1155: } \\
\text { Nature conserva- } \\
\text { tion is made a } \\
\text { priority task and } \\
3 \% \text { of Russia's } \\
\text { terrestrial area are } \\
\text { mandated to be set } \\
\text { aside under strict } \\
\text { protection } \\
\text { - 1995: Law on Pro- } \\
\text { tected Areas }\end{array}$ & $\begin{array}{l}\text { - Authorities: weak; priority on expan- } \\
\text { ding protected area network } \\
\text { - International ENGOs: lobbying for } \\
\text { designation of new reserves and pro- } \\
\text { viding funds and expertise } \\
\text { - National ENGOs: important driving } \\
\text { force for political change and mouth- } \\
\text { piece for societal discontent } \\
\text { - Visitors: visitor numbers are low; } \\
\text { unregulated visitation } \\
\text { - Local population: often antagonistic; } \\
\text { use of resources for livelihoods } \\
\text { - Reserve management: assigned new } \\
\text { tasks but underfunded; often unable } \\
\text { to provide for basic operation of re- } \\
\text { serves; establishment of international } \\
\text { links }\end{array}$ \\
\hline $\begin{array}{l}\text { Antagonism } \\
(2000 \mathrm{~s})\end{array}$ & $\begin{array}{l}\text { - Reduced administrative } \\
\text { weight of nature protection } \\
\text { - No new designations bet- } \\
\text { ween } 2001 \text { and } 2005 \\
\text { - Shift of priorities in desig- } \\
\text { nations from zapovedniki } \\
\text { to national parks } \\
\text { - Protected areas clash with } \\
\text { exploitation of natural } \\
\text { resources as economic } \\
\text { growth picks up } \\
\text { - Budget increases }\end{array}$ & $\begin{array}{l}\text { - 2000: Dissolution } \\
\text { of Goskoméko- } \\
\text { logija } \\
\text { - Integration of na- } \\
\text { ture conservation } \\
\text { into Ministry of } \\
\text { Natural Resources } \\
\text { - } 2001 \text { : Order } 725: \\
\text { reduction of goals } \\
\text { for new designa- } \\
\text { tions of protected } \\
\text { areas }\end{array}$ & $\begin{array}{l}\text { - Authorities: resistance to nature pro- } \\
\text { tection; focus on resource exploitation } \\
\text { - International ENGOs: reduction of } \\
\text { activities } \\
\text { - National ENGOs: consolidation; } \\
\text { taking over from international ENGOs } \\
\text { - Visitors: increasing numbers of } \\
\text { domestic and international visitors } \\
\text { - Local population: increase of partici- } \\
\text { pation in reserve management; dis- } \\
\text { satisfaction with restrictions } \\
\text { - Reserve management: better funding } \\
\text { and equipment }\end{array}$ \\
\hline $\begin{array}{l}\text { Neoliberalism } \\
(2010 \mathrm{~s})\end{array}$ & $\begin{array}{l}\text { - Commodification of pro- } \\
\text { tected areas through brand- } \\
\text { ing and tourism initiatives } \\
\text { - Increased privileging of } \\
\text { revenue generation of } \\
\text { nature protection } \\
\text { - Entrepreneurialism of } \\
\text { protected areas becomes } \\
\text { important } \\
\text { - Uneven geographical im- } \\
\text { pact reflecting accessibility } \\
\text { and attractiveness of re- } \\
\text { serves } \\
\text { - Admission fees planned } \\
\text { from } 2014\end{array}$ & $\begin{array}{l}\text { - 2011: Order 2322: } \\
\text { emphasis on tou- } \\
\text { rism and infra- } \\
\text { structure develop- } \\
\text { ment; construction } \\
\text { of recreational fa- } \\
\text { cilities in protect- } \\
\text { ed areas allowed }\end{array}$ & $\begin{array}{l}\text { - Authorities: focus on creating return- } \\
\text { on-investment } \\
\text { - International ENGOs: reduced level } \\
\text { of significance } \\
\text { - National ENGOs: providing a critical } \\
\text { voice } \\
\text { - Visitors: conflict between typical } \\
\text { high-impact activities and goals of } \\
\text { nature protection } \\
\text { - Local population: dissatisfaction } \\
\text { with restrictions, but slowly growing } \\
\text { benefits from tourism } \\
\text { - Reserve management: growing con- } \\
\text { flict between development and pro- } \\
\text { tection; pressure from central } \\
\text { government }\end{array}$ \\
\hline
\end{tabular}

nations, too, increasingly have to submit to this logic, as is evident in the preference for national parks over strict nature reserves.

In blunt terms, Russian protected areas are urged more and more to transform themselves from sacred cows into cash cows. There is no doubt that the funding situation has improved over the past 20 years and that nature-based tourism offers new chances to disseminate the message of nature protection with a growing part of the Russian population. Evidence suggests, however, that in the trade-off between exploitation and conservation, the cards are stacked against 
the latter. The current political-economic regime means a change in what is valued in nature protection, favouring monetary value creation over conservation. While this may create financial pay-offs in the short run, in the long run it might endanger the very foundations on which this exploitation is built. Yet, what use is a cash cow if it gives no milk?

\section{References}

ARSEL, M. / BÜSCHER, B. (2012): Nature ${ }^{\mathrm{TM}}$ Inc. Changes and continuities in neoliberal conservation and market-based environmental policy. In: Development and Change (43)1, 53-78.

Balmford, A. / Bruner, A. / Cooper, P. / Costanza, R./ Farber, S. / Green, R. E. / Jenkins, M. / JefFeriss, P. / JesSAmy, V. / Madden, J. / Munro, K. / Myers, N. / Naeem, S. / Paavola, J./ Rayment, M. / Rosendo, S. / Roughgarden, J. / TRUMPER, K. / TURNER, R. K. (2002): Economic reasons for conserving wild nature. In: Science, 297, 950-953.

Becken, S. / Job, H. (2014): Protected areas in an era of global-local change. In: Journal of Sustainable Tourism, (22)4, 507-527.

Blaikie, P. (1999): A review of political ecology. Issues, epistemology and analytical narratives. In: Zeitschrift für Wirtschaftsgeographie, (43)3-4, 131-147.

Blaikie, P. / Brookfield, H.C. (1987): Land degradation and society. London.

Blanke, J. / Chiesa, T. (2013): The travel and tourism competitiveness report. Geneva. (World Economic Forum; Internet: http://www.weforum.org/issues/travel-and-tourismcompetitiveness).

Costello, C. / Gaines, S. / Gerber, L. R. (2012): Conservation science: a market approach to saving the whales. In: Nature, 481, 139-140.

Eagles, P. F. J. / McCool, S. F. / Haynes, C. D. (2002): Sustainable tourism in protected areas: guidelines for planning and management. Gland. (IUCN).

FAO (Food and Agricaultural Organization of the UN) (2005): Global forest resources assessment. Rome.

Fiorino, T. / Ostergren, D. M. (2012): Institutional instability and the challenges of protected area management in Russia. In: Society and Natural Resources, 25, 191-202.

Forbes (2012): President Putin's growing gas insanity. In: Forbes, 29 September 2012.

GEF (Global Environmental Facility) (2012): The Russian Federation and GEF. Washington D.C.

Greenpeace (2011): Zapovednik ili „dochodnoe mesto“? Internet: http://www.greenpeace.org/russia/ru/news/2011/ September/01-09-2011-oopt/, 23 June 2013.

HAMPICKE, U. / WÄTZOLD, F. (2009): Memorandum: economics for nature conservation. Greifswald / Leipzig / Bonn.

Herrold-Menzies, M. (2012): Spies in the marsh or postsoviet saviors? Crane conservation and post-Soviet outreach in the Russian Far East. In: Society and Natural Resources, (25) $8,794-807$.
IAKOVleVA, T. / BAY-LARSEN, I. / Kharitonova, G. / DidYK, V. (2012): Entrepreneurship and sustainability in naturebased tourism: the role of institutional profiles in Northern Norway and Northwest Russia. In: Journal of Small Business and Entrepreneurship, (25)4, 433-450.

JoHnson, J. (2012): Sour Olympic legacy. Internet: http:// www.chinadialogue.net/article/show/single/en/5112-SourOlympic-legacy-for-Russia-, 21 June 2013.

Krever, V. / Stišov, M. / OnUfrenja, I. (Eds.) (2009): Osobo oxranjaemye prirodnye territorii Rossii: sovremennoe sostojanie i perspektivy razvitija [Russian protected areas: current situation and development perspectives]. Moscow. (WWF).

KRINGS, T. (2008): Politische Ökologie: Grundlagen und Arbeitsfelder eines geographischen Ansatzes zur MenschUmwelt-Forschung. In: Geographische Rundschau, (60)12, 4-9.

Larin, V. / Mnatsakanyan, R. / Chestin, I. / Shvarts, E. (2003): Ochrana prirody Rossii: ot Gorbačëva do Putina. Moscow. (KMK).

MAYER, M. (2014): Can nature-based tourism benefits compensate for the costs of national parks? A study of the Bavarian Forest National Park, Germany. In: Journal of Sustainable Tourism, (22)4, 561-583.

MAYer, M./Job, H. (2014): The economics of protected areas - a European perspective. In: Zeitschrift für Wirtschaftsgeographie, (58)2-3, 73-90.

MAYer, M. / Müller, M. / Woltering, M. / ArnegGer, J./ JoB, H. (2010): The economic impact of tourism in six German national parks. In: Landscape and Urban Planning, (97)2, 73-82.

MoL, A.P.J. (2009): Environmental deinstitutionalisation in Russia. In: Journal of Environmental Policy \& Planning, (11)3, 223-241.

Moscow Times (2012): Tourism brings revenue and conflict to Russia's park system. In: Moscow Times, 7 June 2012.

MüLLER, M. (2008): Schutzgebiete in Russland: Katalysatoren nachhaltiger Entwicklung? In: Osteuropa, (58)4-5, 419-437.

MüLlER, M. (2014): (Im-)Mobile policies. Why sustainability went wrong at the 2014 Olympics in Sochi. In: European Urban and Regional Studies, (22) (in print).

Müller, M. / ShVArTs, E./ Onufrenya, I. (2011): Nationalparkboom in Russland. In: Natur und Landschaft, (86)2, 64-68.

National Park Service (2012): Budget justifications and performance informatin for FY 2012. Washington D.C. (Department of the Interior).

Newell, J. (2004): The Russian Far East. A reference guide for conservation and development. McKinleyville. ( $2^{\text {nd }}$ ed.).

OSTERGREN, D.M. (2001): An organic act after a century of protection: the context, content, and implications of the 1995 Russian Federation law on specially protected natural areas. In: Natural Resources Journal, (41)1, 125-152.

OSTERGREN, D. M. / JACQUES, P. (2002): A political economy of Russian nature conservation policy. Why scientists have taken a back seat. In: Global Environmental Politics, (2)4, 102-124. 
RoBBins, P. (2012): Political ecology - a critical introduction. Oxford. ( $2^{\text {nd }}$ ed.).

RoBINSON, N. (Ed.) (2013): The political economy of Russia. New York.

Rossijskaja Gazeta (2012): Investorov zovut v park. In: Rossijskaja Gazeta, 28 February 2012.

SchmidT, M. (2013): Mensch und Umwelt in Kirgistan: Politische Ökologie im postkolonialen und postsozialistischen Kontext. Stuttgart.

Schmidt, M./ Doerre, A. (2011): Changing meanings of Kyrgyzstan's nut forests from colonial to post-Soviet times. In: Area, (43)3, 288-296.

Sittler, B. / Tennhardt, T. / Shvarts, E. (2000): Die Schutzgebiete Russlands vor neuen Herausforderungen [Russian protected areas facing new challenges]. In: Natur und Landschaft, (75)1, 1-9.
Smith, A. / Stenning, A. (2006): Beyond household economies: articulations and spaces of economic practice in postsocialism. In: Progress in Human Geography, (30)2, 190-213.

STEPANICKIJ, V. B. (2004): Na perelome. Internet: http://biodat.ru/doc/lib/stepan.htm, 23 June 2013.

Stoll-KleEmann, S. / Job, H. (2008): The relevance of effective protected areas for biodiversity conservation: an introduction. In: GAIA, (17)S1, 86-89.

WEINER, D. R. (1988): Models of nature. Ecology, conservation and cultural revolution in Soviet Russia. Bloomington. WEINER, D.R. (1999): A little corner of freedom: Russian nature protection from Stalin to Gorbachev. Berkeley.

Wells, M.P./Williams, M.D. (1998): Russia's protected areas in transition. The impacts of perestroika, economic reform and the move towards democracy. In: Ambio, (27)3, 198-206. 